\title{
Does Openness, and Productivity Matters for FDI: A Global Interactive Analysis Based on the Complementary Role of Institutions
}

\author{
Humaira Raffat \\ Research Scholar \\ Karachi University Business School, University of Karachi, Pakistan \\ E-mail: humairaraffat@gmail.com \\ Dr. Danish Ahmed Siddiqui \\ Associate Professor \\ Karachi University Business School, University of Karachi, Pakistan \\ E-mail: daanish79@hotmail.com
}

Received: June 2, 2020

Accepted: July 20, 2020

Published: July 22, 2020

doi:10.5296/ieb.v6i2.17402

URL: https://doi.org/10.5296/ieb.v6i2.17402

\begin{abstract}
Conventional wisdom suggested that investment flows in where you have abnormal returns that resulted in a high productivity area. However, FDI behaves peculiarly, as most are targeted towards developed countries where excess competition drives down returns and ultimately productivity. On the contrary, it shy in developing countries where one has more productive investment opportunities. This study tries to tackle the problem and explores the factors that influenced FDI flows. In particular, we focused on productivity, trade openness, financial liberalization, and institutions. Macro-level data was collected from 27 economies from 2004 to 2015. The analysis was done using GMM methodology. The results showed productivity remained insignificant in explaining FDI throughout the models. Trade seems to have a significant positive impact on the model without the interaction effect. Interestingly, financial liberalization seems to affect FDI negatively in all cases. GDP growth had a positive and significant effect. All Institutional variables that include control of corruption, government effectiveness, regulatory quality, rule of law, seems to have a significant positive impact on FDI individually, as well as in the combined form. We also witnessed significant and positive complementarities with each of the institutional factors and productivity, in


explaining FDI. This indicated that higher productivity is not the deciding factor of FDI, however, the same productivity in a better institutional environment would produce positive complementarity that would significantly determine FDI. The findings imply that investors' prime concern is not productivity but the institutional environment. Moreover, only with quality institutions, the conventional wisdom persists.

Keywords: Foreign direct investment, productivity, financial liberalization, GDP growth, institutional quality, trade openness.

\section{Introduction}

\subsection{Background of the Study}

The foreign direct investment FDI in the growth of an economy played very important roleand also used in different Hypothetical and experiential studies (Akbes et al., 2013), (Laura et al, 2004 and 2006), (Xiaoying \& Xiaming 2004), (Chong et al., 2004), (Omran \& Bolbol 2003), (Borensztein et al., 1995) and (De Mello 1999). So it would clarify mostly that FDI is hypothetical an effective instrument in the transmission of the expertise advanced to emerging countries. Also, FDI is usually gazed as an imperative sourc to permit industrialized expansion in the congregation country and it's concrete in emerging nations. Additionally, FDI as rapidly as recognized it can produce optimistic belongings in product efficiency attractiveness and occupation construction in congregation countries.

The influence of FDI is replicated not only resolved resources input for the congregation country but also influence in relations of skill and expertise as well as to right of entering in new markets.

FDI also offer in a dynamic technique to economic growth and development (Goa, 2004). Many economists, academicians policymakers, and the management expert have described it is an important source of more production enhancement of efficiency growth of new technology and management of the firm and useful link to the world market of developed and underdeveloped countries. Therefore it is significant to recognize the role of foreign direct investment in the context of the economy (Chakraborty \& Peter, 2007).

Here some of the crucial issues are; (1) Do FDI increase GDP growth by improving productivity, growing efficiency, generating job opportunities, increasing trade, bringing in a new organization, and production performances? (2) Do the lower GDP growth in the long run by taking extreme profits attainable of the economy? (Agerwal, 2003). The impact of FDI inflows in any economy is of two categories namely direct and indirect. The direct effect of FDI inflows contains an impact on domestic investment, revenue employment, productivity, a price equal, and export growth. Besides that, there is also a surplus of another impact that affects the domestic economy indirectly. The FDI Spillovers effect used to entrance and occurrence of Multinational corporations raises productivity of local businesses in the mass country and the multinationals prepare not entirely affect the significance of those profits.

As a determinant financial liberalization played an essential role for the development of the financial sector but it is not enough to boost venture in new technologies as well as in the technical growth. In additional, as per the domestic financial segment is increasing risks related to revolutionizing old and new technologies drive concentrated. The progress of the domestic 
financial segment permits external organizations to derive in instruction to escalation of forward- looking accomplishments in the mass nation. So it might escalation high-tech externalities to native businesses. The accessibility or eminence of nationwide fiscal facilities could effect the FDI and skill dispersion in the mass nation. The distribution development can be more suitable when the financial segments in the host nation are well established. This permits the international subsidiary toward escalation of its investment once it is established in the host nation. Besides, the transformation of prevailing technology and the implementation of fresh technologies are acquaint by foreign organizations.

Now it has been summarized that, the appropriate operation of fiscal systems can increase FDI effects on growth in host nations. Practically, it is noticed that the financial segments may affect both investors and industrial activities. Thus the moral efficiency of the local fiscal system inspires production accomplishments and fascinates additional FDI.

The effects of FDI inflows into the economy are of two types specifically direct and indirect. The direct influence of FDI inflows contains influence on domestic investment, income, employment, productivity, price level, and export growth. Furthermore, there are also surpluses of additional impacts on the effect of the domestic economy indirectly.

The FDI Spillovers effect used to entrance and occurrence of Multinational corporations raises the efficiency of local businesses in the mass nation and multinationals prepare not entirely affect the worth of the profits. When any company with advanced productivity makes access then it naturally inspires other organization of the same sector to improve and advance the skills, performance and the compitencies.

World Bank (2008) states financial globalization of the growth in the distribution sector of the economy is rapidly increase in different countries of the world. This obligates controlled toward an argumentative discussion that whether the countries are progressively and the stingily combined with the other countries of the world. The accumulative globalization and interconnection between nations over past layout and trade associations, Ertur and Koch (2007) also conclude that high-tech inter dependence produced by external is essential in descriptive the restrictive meeting progression across countries.

The study and the analyizment of Productivity also identifies the significance of spillover effects examine in the worldwide industry cycles. Mastromarco et al. (2013) determine that it is significantly essential in the direction of financial globalization aspects aimed at an investigation of efficiency and production growth. Moreover, the countries have a tendency to be influenced through their neighbor countries in a slightly intricate way such interconnections reduce idealistic the supposition of agent's equality.

\subsection{Problem Statement}

For foreign investment, that country's labor force must be skilled, because FDI does not always depend on capital investment. Most of the time host companies want to invest in the skilled labor force because this kind of investment technological advancement is possible. But unfortunately, those economies where a major economic share is based on the agricultural sector, their labor is not well educated. And this is the reason from which foreign companies do not take interest to invest in developing countries.

Above mentioned reason is not the only one due to which investor does not take interest 
to invest in developing countries. Still, there is a need to discuss those reasons which demotivate foreign investors to invest. In most developing countries uncertainty is very common in the economic and political fields. That affects the economic growth of the country and due to this most of the developing economies faced low GDP rates as compare to others. Normally in developing countries resources are very scare even they are not able to fulfill their basic need.

In many developing countries, crime rate, corruption rate, and other illegal activities are much higher than the developed countries and the government is not able to control them this also affects the country's GDP very badly. Because of these activities, economic growth and development affected very badly. So, for developing countries investment is needed in those sectors of the economy which will boost their economic growth.

FDI's impact on productivity in developing and developed countries is determined through different research papers. Some concluded that FDI impact is positive on productivity while some evidence available on their negative relation. But still, there is a need to analyze updated data, also a new variable incorporated to find out their effect on FDI. This study finds out the impact of FDI on productivity and financial liberalization using the Kaopen Index.

\subsection{Gap Analysis}

There is a lack of study focusing on the consequence of FDI on different variables like growth, finance, economic development, North vs the South convergence, etc. (Alfaro \& Chauvin, n.d.; Demena, n.d.; Demir \& Duan, 2018; Dupasquier \& Osakwe, 2006; Eddine, n.d.; Elkhuizen et al., 2018; Francis et al., 2009; Hallam, 2011; Hausmann \& Fernández-Arias, n.d.; Herzer et al., 2008; Jaiblai \& Shenai, 2019; Kose et al., 2009)

Most of these studies absorbed on the spillover special effects of FDI on the economies. Many studies also focused on the spillover effect of FDI on productivity (Ajide \& Raheem, 2016; Albuquerque, 2003; Bhattacharyya, 2012; Cleeve, 2008; Kose et al., 2009; Nunnenkamp, 2001; Singh, 2003). It is seen that from the literature review that the FDI inflow on productivity is mixed positive or negative.

Despite this massive literature, very few studies focused on the antecedents of FDI on a macro level. Specifically, why there is a disparity in FDI flows. Some studies explore control influential elements that would affect FDI inflows of an economy. For example (Saidi et al., 2013; Busse \& Hefeker 2005; Bouchoucha \& Ammon 2015) explored these factors for developed and developing, Alemu (2013) done for Asian countries, Wernick, Haar, and Sharma (2014) explored African nations and Daude, and Stein (2001) done on OECD nations specifying that political and institutional element may interupt is primary flow of FDI.

However, according to empathetic, there is no previous revision and studies that focused on important determining factor of FDI like productivity and openness. Therefore a need to assess the impact of FDI inflows on productivity using more recent data at a different sectorial level. This study tries to tackle the problem and explores the factors that influenced FDI flows. In particular, we focused on productivity, trade openness, financial liberalization, and institutions. We also try to explain why FDI behaves disparately. For 
this, we introduced a complementarity effect of institutions along with productivity in explaining FDI flows. This is a novel attempt as no such study neither explores the effect of Productivity on FDI nor gives a possible explanation behind this relationship, specifically with the perspective of governance institutions.

\subsection{Research Objectives}

This study tries to tackle the problem and explores the factors that influenced FDI flows. In particular, we focused on productivity, trade openness, financial liberalization, and institutions. Macro-level data was collected from 27 economies from 2004 to 2015, in which a total of 11 countries are developed countries whereas 16 countries are developing economies of the world. We also try to explain why FDI behaves disparately. For this, we introduced a complementarity effect of institutions along with productivity in explaining FDI flows. For governance variable, Government Efficiency, Regulatory Quality, Rule of Law, and Control of Corruption is used.

\subsection{Research Question}

For finding out the above-mentioned core objectives of this study, the following question is used for evaluating this impact.

- Does productivity positively influence FDI

- Does financial liberalization related to FDI

- Does Trade openness influence FDI

- Does Governance institutions affect FDI

- In there complementarities among institutions and productivity in explaining FDI

\subsection{Significance}

This study helps to understand the importance of foreign direct investment for productivity, financial liberalization, and trade openness, and governance institutions. This study fulfilled the research gap in the literature on foreign direct investment and productivity. The study is also helpful for policymakers for policy development.

\section{Literature Review}

\subsection{FDI and Economic Growth}

In this section we review the main studies investigating the effect of foreign direct investment FDI versus productivity, financial liberalization the literature devoted to institutional quality. Also, it works in dealing with the role of trade openness in the economy.

The influence of foreign direct investment (FDI) in financial evolution the focus of numerous hypothetical and experimental studies (Akbes et al., 2013); Laura, A et al. (2004 and 2006); Xiaoying, L and Xiaming, L (2004). Choong, C. K et al. (2004); Oman, M, and Bolbol, A., (2003); Borensztein, E., J. Gregorio, and J.W. Lee (1995) and De Mello, L. R., (1999)). It has been clarified mostly through the element that FDI is fictionally remain an operative tool of technological transmission and expertise from advanced to emerging countries. In addition, it is commonly observed that the FDI played important reserve to empower development of the industries in the host nation and specifically in under develop countries. Furthermore, once FDI recognized can prevent a optimistic sound belongings on productivity, effectiveness, and 
employments in mass nations. Certainly the influence of the FDI transmitted not only from investment contributions for the host country on the other hand it is also influence in relations of tools and expertise for instance exactly how to entrance in the new markets. FDI may also helpful in the contribution of dynamic technique in the country development and economic growth (Grossman and Help man (1991), Baror and Sala-i- Mar t in (1995), and Goa (2004).

More newly, Slesman et al. (2015) extant resilient indication about foreign investment arrivals containing FDI ensure a positive effect in the growth of countries through unrivaled institutions, even though the countries that collapse under the recognized edge of institutional quality weather adverse or immaterial effects. Also some of the studies recommend features for example trade openness, fiscal growth, investment, outside liability, macroeconomic rule, financial independence, institutional quality, and bribery also establish appropriate emergency aspects upsetting the FDI evolution association (Balasubramanyam et al., 1996; Hermes and Lensink, 2003; Alfaro et al., 2004; Mallick and Moore, 2008; Azman-Saini et al., 2010, Alguacil et al., 2011; Bekaert et al., 2011; Okada and Samreth, 2014; Tanna et al., 2018). Furthermore, some reviews show optimistic evolution belongings of FDI regardless their adapting aspects. Hansen and Rand, 2006; Herzer and Klasen, 2008; Hsiao and Hsiao, 2006 although some suggested that FDI may not employ a strong, optimistic and sovereign impact in the growth of economy (Carkovic and Levine, 2005; Gorg and Greenaway, 2004).

Indeed associated with micro level studies examine the special effects of spillover among productivity and the FDI for different under developed countires, these studies and literature unable to pay fully attention on underdeveloped in a broader picture as entire. Initial study De Mello (1999) discover helpful indication of total factor of production evolution belongings through FDI in cross country model of developed and emerging countries although innovative adaptations by Bekaert et al. (2011) and Kose et al. (2009) deliver a wider indication of optimistic TFP development belongings through financial openness. Alfaro et al. (2009) also indicated the benefits contemporary cross country indication to recommend that countries with well-developed monetary markets attain evolution assistances through FDI versus TFP growth regardless from influence accrual.

Bekaert et al. (2011) and Kose et al. (2009) highlight the standing of institutional quality in producing advanced TFP growth from financial openness, while Borensztein et al. (1998) and Cooray et al. (2014) highlight the significance of man resources in elastic positive growth belongings from openness through trade and FDI.

Bekaert, Harvey, \& Lundblad (2010) also provide a revision demonstration that financial openness improves the features and the excellence of the financer shelter in cross country study. Besides, that there is organizations who issue stock or debt in other countries also have some possible features to study the operative corporate governance of other countries.

There are two networks through which capital account liberalization affects economic growth as distinct within the classical framework (Bekaert et al., 2011). The first liberalization of capital decides the effort of capital from rich countries to poor countries where interest is high.

Second, the literature of international finance specifies that liberalized equity markets decline the equity risk premium from enhanced risk-sharing. The final shared with the 
foreign contribution in local capital markets guarantees the maintenance of a stable state level of GDP (Bekaert et al., 2011). Concerned by the promises of financial liberalization hypothesis in developing countries implemented financial liberalization process in the 1980 s and many of them secured massive benefits.

\section{Theoretical Approaches to FDI}

The initial descriptions of FDI remain situated in the models transmitted by Heckscher-Ohlin (1933) and MacDougall (1960) and Kemp (1964), it stated as the MacDougall-Kemp model, which suggested that FDI encouraged by advanced effectiveness among foreign markets through appreciating progress and cheap labor budgets and exchange threats.

Authors such as Hymer (1976) and Kindleberger (1969) consider that there should be inadequacies in the markets for material good and elements of construction for FDI. Hymer (1976) similarly indorses that investment out of the country involves extraordinary expenses and threats intrinsic toward the shortcomings handled by multinationals as they are external. This contain the rate of attaining evidence because of traditional and linguistic dissimilarities and the rate of a reduced amount of favorable behavior by way of government of host nations. The multinationals will consequently have the possession benefits (e.g., inventive products, organization expertise, rights, and so on) to balance the shortcomings. In expressions of possession benefits, Caves (1971) absorbed the review on product diversity in the acceptance that FDI has a benefit in the trade and permitting of product diversity is established on information.

Knickerbocker (1973) compare the study between the firm's competition and the FDI. He reveals that the flow of the FDI redirect the planned competition among firms in the worldwide market as an outcome of responsive behavior of rivals to enter in influenced markets. On the other hand, organizations frequently ensure derivative activities. It also seems that there is a competition in the international market that will not increase a tactical benefit (Knickerbocker, 1973). It will also affects the decision of the production cost among the rival firms which become more competitive exploration of the theory of product life cycle Vernon (1966). He also suggested that direct investment in the firms is better rather than to choose an alternative spreading. The bend of the life cycle (growth, maturity, and decline), is tend to extent the decline the firms needs in terms of dedicated labor and advanced expertise. In the evolution phase, organizations finance in other advanced countries somewhere markets are rising and native production can be engaged, even though in the maturity and decline stages production is lifted to emerging nations science marketplaces turn into flooded and products be situated less advanced, thus producing gravity to decrease costs (Hill, 2007). Aharoni (1966) clarified why organizations choose FDI for rivalry elements, such as the panic of damage of attractiveness, the requirement to survey competitors into foreign markets, and enlarged competition in the domestic market. Internalization concept was initially introduced by Buckley and Casson (2010), who argued that organizations select to internalize procedures through FDI when operation outlays (such as statistics and intervention expenditures, market resourse) are advanced than internalization outlays (related to in-house announcement and organization). As soon as market threat and improbability are high then contract expenses are increase, and internalization of operations is preferred (undertaking FDI). 


\section{Macrothink}

The dunning tactic are the heterogeneous or OLI model squeezes the internalization model and traditional trade theories. (Dunning, 2002), then systematizes the advantage for organizations that function internationally, linking them to the selected entrance. There are benefits in selecting FDI when there are all together possession compensations - O, locality benefits - L internalization benefits - I. Possession benefit concerns the significance of a firm retaining resources such as innovative expertise, exclusive dynamic procedures, exclusive rights, administration abilities and such like, that can produce revenues in the future (Dunning \& Lundan, 2008).

Institutional theory recommends that organizations mechanism in a merged situation that is indeterminate and occasionally argumentative, and therefore a organization's resolutions will be governed by the institutional services that influence it, specifically on code of practice and inducements (Francis et al., 2009). In this background, the policies implemented by organizations and their performance on worldwide markets are mostly resolute by institutions, by the "rules of the game" (Peng, 2009). External investment can therefore be observed as a 'game' in which the troupes are the multinational firm and the government of the host country, or as a challenge among governments to draw FDI.

Corruption is similarly imperative, issue in firms' choices to indicate for a specific place. Bénassy-Quéré et al. (2007) and Cleeve (2008) remain in the middle of those authors who say that low levels of corruption are related to larger prosperity and need a substantial effect on the institutional excellence of a country, and stimulate its expansion and growth.

\section{Method}

\subsection{Data Measurement and Sources}

This empirical research investigates the impact of FDI on the productivity and the efficiency moderation of financial liberalization of the economy in 27 countries. To estimate the model, this study employed the panel data of 27 selected countries based on the availability over the period (2004-2015). The sample size consists of 324 observations based on secondary data. The data-sets were collected mainly from world development indicators (WDI), world governance indicators (WGI), and Asian productivity database (APO). The FDI and the trade openness (TO) GDP growth data were collected from WDI. The productivity data was taken from the APO database of productivity measurements and the financial liberalization (KI) data was collected from the Chin-ITO financial openness index. In the direction of explanation for controller variables in the fiscal policies, the study used the following as control variables government effectiveness, regulatory quality, rule of law, and control of corruption were collected from WGI. Concerning the variables, it is noted that the concept delivers has no clear rules about those that must be involved in growth balance. Therefore according to the objectives of the study different illuminating variables were reserved and theoretical important in the literature. The variables which are used in the empirical investigation are essential indicators of economic growth.

The data were analyzed by using the Panel Regression effect and GMM model effect to determine how productivity affects the FDI? Factor analysis effects of institutional quality and missing data analysis of KI also used to reduce errors. FDI was taken as the 


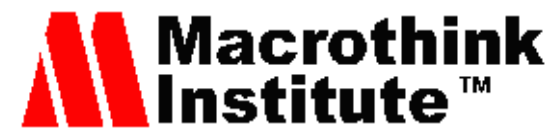

dependent variable while productivity and trade openness as independent variables. The other control determinants of financial liberalization and GDP growth were used. To find out the results and effects EVIEWS and SPSS software were used. To study how FDI is related to trade openness, institutional quality financial liberalization, and study how productivity affects the FDI basic formal relationship was used with some modifications.

\subsection{Econometric Modeling}

Based on the procedure of Arellano-Bond Approach the study examines the effect of panel regression, following a dynamic panel model was employed:

Where FDI is the foreign direct investment, GDP of economic growth, PRO is the proxy variable of the number of employment of labor productivity, TO is the indicator of trade openness, KI represents the financial liberalization, control variables including CONCOR as control of corruption, GOVEFF as government efficiency, REQUA as regulatory quality and LAW as rule of law, $i$ denotes the country and $t$ indicates the period time and $\mu$ is the error term. We also determined WGI (factor) as a model of factor analysis of institutional quality. The interaction term between productivity and the institutional quality was used to measure the influence and effect on FDI. The study explored the panel regression model and used the general methods of moments (GMM) under empirical investigations from other similar studies.

Panel regression is estimated by using pooled least square, fixed data, and random data.Now this research, random effect and the linear GMM used to estimate the dynamic panel model permitting to the Arellano-Bond Approach. The Occurrence of autocorrelation in command to and the instrument invalidity in maximum regressions entails the use of the GMM system method. This technique settles taking into explanation the homogeneity of the countries to indenture with the variables regularity problem. The GMM method remains used in current studies, in identifying; those review the association between progress of productivity and the FDI and the financial liberalization and growth. These estimators were intended for circumstances with independent variables continue not exogenous science they are correlated with past relations and the auto-correlation within individual variables. The dependent variables were enclosed to capture the past association. We suppose this model to internment the flaws of the past models with econometric difficulties. It is on the consequences of this technique that generally based on conclusions.

Model 1 a:

\begin{tabular}{|l|l|l|l|}
\hline Variables & Coefficient & t-Statistic & Prob. \\
\hline FDI-I-G(-1) & 0.438993 & 40.64934 & 0.00 \\
\hline PRO & 0.94454 & 0.365426 & 0.7151 \\
\hline TO & $7.46 \mathrm{E}-12$ & 2.768613 & 0.006 \\
\hline KI & -4.2073 & -5.01802 & 0.00 \\
\hline GDP- AG & 0.717738 & 52.34006 & 0.00 \\
\hline CONCOR & 13.11746 & 11.46018 & 0.00 \\
\hline
\end{tabular}

Model 1 a: The results indicate that there is a positive and significant relationship among the 
variables but the negative sign of the coefficient of KI has shown a negative but significant relationship of financial liberalization. That's shows when FDI increases its effect negatively on financial liberalization. The relationship between FDI and productivity is insignificant. The institutional quality (including control of corruption) has a significant positive impact on FDI.

Model 1 b:

\begin{tabular}{|l|l|l|l|}
\hline Variables & Coefficient & t-Statistic & Prob. \\
\hline FDI-I-G(-1) & 0.427637 & 16.77396 & 0.00 \\
\hline PRO & 6.163776 & 1.368077 & 0.1725 \\
\hline TO & $4.71 \mathrm{E}-12$ & 1.028633 & 0.3046 \\
\hline KI & -5.89336 & -2.99461 & 0.003 \\
\hline GDP-AG & 0.69892 & 21.58222 & 0.00 \\
\hline CONCOR & -0.54629 & -0.10751 & 0.9145 \\
\hline CONCOR*PRO & 10.84827 & 2.047882 & 0.0416 \\
\hline
\end{tabular}

Model 1 b: The interaction terms between institutional qualities with productivity provide new and interesting shreds of evidence. The combination of institutional quality and productivity has a positive effect on FDI. The institutional quality has a significant negative impact on FDI.

Model 2 a:

\begin{tabular}{|l|l|l|l|}
\hline Variables & Coefficient & t-Statistic & Prob. \\
\hline FDI-I-G(-1) & 0.418748 & 15.78544 & 0.00 \\
\hline PRO & 6.874926 & 1.049126 & 0.2951 \\
\hline TO & $3.45 \mathrm{E}-12$ & 0.545935 & 0.5856 \\
\hline KI & -2.430469 & -0.646692 & 0.5184 \\
\hline GDP- AG & 0.659445 & 11.21507 & 0.00 \\
\hline GOVEFF & 7.098488 & 3.387623 & 0.0008 \\
\hline
\end{tabular}

Model 2 a: The results indicate that there is a positive and significant relationship among the variables but the negative sign of the coefficient of KI has shown a negative but significant relationship of financial liberalization. The relationship between FDI and productivity insignificant. The institutional quality has a significant positive impact on FDI. 
Model 2 b:

\begin{tabular}{|l|l|l|l|}
\hline Variables & Coefficient & t-Statistic & Prob. \\
\hline FDI-I-G(-1) & 0.389045 & 12.75811 & 0.00 \\
\hline PRO & 3.385786 & 0.522304 & 0.6019 \\
\hline TO & $2.28 \mathrm{E}-12$ & 0.541664 & 0.5885 \\
\hline KI & -2.443663 & -2.06286 & 0.0401 \\
\hline GDP-AG & 0.694184 & 13.73679 & 0.00 \\
\hline GOVEFF & -13.79477 & -3.40402 & 0.0008 \\
\hline GOVEFF*PRO & 15.79439 & 4.252777 & 0.00 \\
\hline
\end{tabular}

Model 2 b: The interaction terms between institutional qualities with productivity provide new and interesting evidence. The combination of institutional quality and productivity has a positive effect on FDI. The institutional has a significant negative impact on the FDI.

Model 3 a:

\begin{tabular}{|l|l|l|l|}
\hline Variables & Coefficient & t-Statistic & Prob. \\
\hline FDI-I-G(-1) & 0.394876 & 20.6475 & 0.00 \\
\hline PRO & -2.924375 & -1.070745 & 0.2853 \\
\hline TO & $8.20 \mathrm{E}-12$ & 3.633805 & 0.0003 \\
\hline KI & -5.753033 & -4.340195 & 0.00 \\
\hline GDP-AG & 0.741406 & 24.98881 & 0.00 \\
\hline REQUA & 11.53608 & 18.52387 & 0.00 \\
\hline
\end{tabular}

Model 3 a: The results indicate that there is a positive and significant relationship among the variables but the negative sign of the coefficient of KI. The institutional quality has a significant positive impact on FDI.

Model 3 b:

\begin{tabular}{|l|l|l|l|}
\hline Variables & Coefficient & t-Statistic & Prob. \\
\hline FDI-I-G(-1) & 0.379477 & 7.685395 & 0.00 \\
\hline PRO & 5.796994 & 2.076799 & 0.0388 \\
\hline TO & $-1.85 \mathrm{E}-13$ & -0.097209 & 0.9226 \\
\hline KI & -4.744851 & -2.27471 & 0.0237 \\
\hline GDP-AG & 0.683375 & 15.75706 & 0.00 \\
\hline REQUA & -17.98193 & -1.516425 & 0.1306 \\
\hline REQUA*PRO & 21.09628 & 2.519994 & 0.0123 \\
\hline
\end{tabular}

Model 3 b: The interaction terms between institutional qualities with productivity provide new and interesting evidence. The combination of institutional quality and productivity has a positive effect on FDI. 
Model 4 a:

\begin{tabular}{|l|l|l|l|}
\hline Variables & Coefficient & t-Statistic & Prob. \\
\hline FDI-I-G(-1) & 0.417217 & 28.99603 & 0.00 \\
\hline PRO & -0.986644 & -0.927862 & 0.3543 \\
\hline TO & $6.10 \mathrm{E}-12$ & 18.52387 & 0.00 \\
\hline KI & -5.707398 & -8.936174 & 0.00 \\
\hline GDP- AG & 0.800131 & 167.8445 & 0.00 \\
\hline LAW & 12.81265 & 6.793515 & 0.00 \\
\hline
\end{tabular}

Model 4 a: The results indicate that there is a positive and significant relationship among the variables but the negative sign of the coefficient of KI. That's shows when FDI increases its effect negatively on financial liberalization. The institutional quality (regularity quality) has a significant positive impact on FDI.

Model 4 b:

\begin{tabular}{|l|l|l|l|}
\hline Variables & Coefficient & t-Statistic & Prob. \\
\hline FDI-I-G(-1) & 0.40561 & 8.48306 & 0.00 \\
\hline PRO & 8.883192 & 1.156099 & 0.2487 \\
\hline TO & $1.55 \mathrm{E}-12$ & 0.478728 & 0.6325 \\
\hline KI & -9.072482 & -5.202273 & 0.00 \\
\hline GDP-AG & 0.660259 & 16.56411 & 0.00 \\
\hline LAW & -22.63696 & -2.816662 & 0.0052 \\
\hline LAW*PRO & 24.01582 & 4.67941 & 0.00 \\
\hline
\end{tabular}

Model 4 b: The interaction terms between institutional qualities with productivity provide new and interesting evidence. The combination of institutional quality and productivity has a positive effect on FDI.

Model 5 a:

\begin{tabular}{|l|c|c|l|}
\hline Variables & Coefficient & t-Statistic & Prob. \\
\hline FDI-I-G(-1) & 0.381929 & 17.67057 & 0.00 \\
\hline PRO & -6.725478 & -2.543378 & 0.0115 \\
\hline TO & $9.23 \mathrm{E}-12$ & 3.761695 & 0.0002 \\
\hline KI & -4.039802 & -4.276215 & 0.00 \\
\hline GDP- AG & 0.76985 & 43.57784 & 0.00 \\
\hline FAC OF WGI VARIABLE & 24.64531 & 15.01779 & 0.00 \\
\hline
\end{tabular}

Model 5 a: The results indicate that there is a positive and significant relationship among the variables but the negative sign of the coefficient of KI. The factor of institutional quality ((including government effectiveness, regulatory quality, rule of law, and control of corruption) has a significant positive impact on FDI. 


\section{MlMacrothink}

Issues in Economics and Business

ISSN 2377-2301

2020, Vol. 6, No. 2

Model 5 b:

\begin{tabular}{|l|l|l|l|}
\hline Variables & Coefficient & t-Statistic & Prob. \\
\hline FDI-I-G(-1) & 0.407918 & 13.05432 & 0.00 \\
\hline PRO & -2.09849 & -0.656707 & 0.5119 \\
\hline TO & $6.64 \mathrm{E}-12$ & 2.04168 & 0.0422 \\
\hline KI & -6.166587 & -3.598802 & 0.0004 \\
\hline GDP- AG & 0.740824 & 23.08761 & 0.00 \\
\hline FAC OF WGI VARIABLE & 7.101316 & 0.973908 & 0.331 \\
\hline PRO*FAC OF WGI VARIABLE & 10.87991 & 1.991257 & 0.0475 \\
\hline
\end{tabular}

Model 5 b: The interaction terms between institutional qualities with productivity provide new and interesting evidence. The combination of institutional quality and productivity has a positive effect on FDI. The factor of institutional quality ((including government effectiveness, regulatory quality, rule of law, and control of corruption) has a significant positive impact on FDI.

\section{Discussions}

The purpose of this study is to find out that foreign direct investment creating an impact on productivity, financial liberalization, and trade openness and governance institution in 27 countries of the world. According to established wisdom, productivity should positively affect foreign direct investment, but it is insignificant in the model. Investment flows in where you have abnormal returns that resulted in a high productivity area. This has also reveled in the results. Results seem to suggest that productivity is not driving the FDI flows at least at the macro level. One possible explanation is FDI is more prone to risk rather than returns One of the prominent risks affecting these flows is political uncertainty and bad governance.

These institutions provide community things such as integrity and regulation that drive to defend property rights, reduction deal charges by applying agreements, and development evolution.

Hence countries with low-quality institutions seem to offer a higher risk to investment. And this risk would counter off higher productivity benefits. This also explained significant and positive complementarities with each of the institutional factors and productivity, in impacting FDI. This means, where institutions are strong, the risk related to governance and political instability is not that strong to offset productivity gains, hence higher the institutional quality, stronger the relationship between productivity and FDI. Moreover, All Institutional variables that include control of corruption, government effectiveness, regulatory quality, rule of law, seems to have a significant positive impact on FDI individually, as well as in the combined form. This indicated that higher productivity is not the deciding factor of FDI, however, the same productivity in a better institutional environment would produce positive complementarity that would significantly determine FDI.

In this study, the Kaopen index used as a proxy of financial liberalization, and the Kaopen index measures the capital account openness of a country. It shows financial liberalization seems to affect FDI negatively in all cases.

Trade openness is generated by adding imports and exports of the country, it measures the 
country's trade condition in the international market. If a country's exports are greater than their imports this indicates that there is a surplus in trade. This supports the theory that Growth is the culmination of all the positive factors that could affect and risk and return relationship of FDI. Hence seems to affect FDI positively.

Good governance ensures participation, rule of law, transparency, responsiveness, consensus-oriented, equity and inclusiveness, effectiveness and efficiency, and accountability. Hence, for growth and development not only productivity, financial liberalization, and trade openness plays an important role, but good governance is also a key element factor for it.

\section{Conclusion}

This study has observed the influence of FDI versus productivity financial liberalization on economic growth, specified the inconsistency and the gap in the literature, using a sample of 324, from 27 developing and developed countries during the period 2004-2015. This study utilized a dynamic panel estimation approach to examine the linkage. However a numeral of papers have been published in countries during the period of the affiliation among FDI, productivity, financial liberalization, and growth. The number of researches conducted on the topic of foreign direct investment and productivity, but no such study found out in which financial liberalization, trade openness, and governance institution are included as a repressor in estimating FDI. Based on the gap analysis of the study, this paper enhances to the current experimental indication in two techniques.

Firstly, the study empirically examined the effect of productivity on FDI along with the impact of different other variables in developing and developed countries. The result as shown the overall positive effects of productivity on FDI however it is insignificant. However, when institutions were introduced as moderator, it shows positive complementarities between productivity and institutions in explaining FDI. This suggested institutions not only directly affect FDI but also strengthen the relationship between productivity and FDI.

Secondly, the study provides to the works; since it judgmentally observes the role of FDI in productivity growth and the financial liberalization in terms of trade openness. The results indicate that there is a positive and significant relationship among the variables but the negative sign of the coefficient of trade openness has shown a negative but significant relationship of trade openness. That's shows when FDI increases its effect negatively on trade openness.

The interaction terms between institutional qualities with productivity provide new and interesting evidence. The combination of institutional quality and productivity has a positive effect on FDI. The factor of institutional quality ((including government effectiveness, regulatory quality, rule of law, and control of corruption) has a significant negative impact on FDI. The summary of the study is that the main reasons of productivity and the FDI, we resolute alternative inspiring aspect that give the impression to have an optimistic influence on the relationship between productivity and FDI, that of fiscal expansion in particular as liberalized one.

The study implies that control matters have to be implicit in the framework of the neoinfluential revolution in societal knowledge. Thus it is incomplete without empathetic of the governmental framework determining the circumstances for the escalation of the good governance dissertation in worldwide public procedure. The problem is identify that how the 
institutional improvements of misgoverned implement in the country to reinforce the political fundamentals of a country economics system.

Managing the political restrictions significant economic and institutional variation is possibly the best thoughtful exclusion of the good governance tactic to growth.

This study helpful for policymakers and foreign investors to build those policies which are in favor of investor and economy both. This study helpful for understanding the importance of foreign direct investment for increases in productivity, economic growth, financial liberalization, trade openness, also for good governance institutions in the economy.

\section{References}

Agarwal, P. (2003). Economic Impact of Foreign Direct Investment in South Asia', Chapter 6 in India and the WTO, edited by Aditya Mattoo and Robert M. Stern, published by World Bank and Oxford University Press, Washington, DC.

Aharoni, Y. (1966). The foreign investment decision process (Vol. 403). Boston: Division of Research, Graduate School of Business Administration, Harvard University.

Ahmed, S. (2012). On being included: Racism and diversity in institutional life. Duke University Press. https://doi.org/10.1215/9780822395324

Aitken, B. J., \& Harrison, A. E. (1999). Do domestic firms benefit from direct foreign investment? Evidence from Venezuela. American economic review, 89(3), 605-618. https://doi.org/10.1257/aer.89.3.605

Ajide, K. B., \& Raheem, I. D. (2016). Institutions-FDI Nexus in ECOWAS Countries. Journal of African Business, 17(3), 319-341. https://doi.org/10.1080/15228916.2016.1180778

Akbas, Y. E., Senturk, M., \& Sancar, C. (2013), Testing for causality between the foreign direct investment, current account deficit, GDP and Total credit: Evidence from G7. Panoeconomicus, 60(6), 791-812. https://doi.org/10.2298/PAN1306791A

Albuquerque, R. (2003). The composition of international capital flows: Risk sharing through foreign direct investment. Journal of International Economics, 31. https://doi.org/10.1016/S0022-1996(03)00013-8

Alemu, A. M. (2013). Quality of institutions and FDI inflow: evidence from Asian Economies. Korean Review of International Studies, 35-57.

Alfaro, L., \& Chauvin, J. (n.d.). Foreign Direct Investment, Finance, and Economic Development, 32.

Alfaro, L., A., Chanda, S., Kalemli-Ozcan \& Sayek (2004), 'FDI and Economic Growth: The Role of Local Financial Markets. Journal of International Economics, 64, 113-34. https://doi.org/10.1016/S0022-1996(03)00081-3

Alfaro, L., A. Chanda, S. Kalemli-Ozcan and S. Sayek (2006), 'How Does Foreign Direct Investment Promote Economic Growth? Exploring the Effects of Financial Markets on Linkages', NBER Working Paper 12522. https://doi.org/10.3386/w12522

Alguacil, M., Cuadros, A., \& Orts, V. (2011) 'Inward FDI and Growth: The Role of Macroeconomic and Institutional Environment'. Journal of Policy Modeling, 33(3), 481-496. https://doi.org/10.1016/j.jpolmod.2010.12.004

Aliber, R. Z. (1970). A theory of direct foreign investment. The international corporation, 
12-36.

Arnold, J. M., \& Javorcik, B. S. (2009). Gifted kids or pushy parents? Foreign direct investment and plant productivity in Indonesia. Journal of International Economics, 79(1), 42-53. https://doi.org/10.1016/j.jinteco.2009.05.004

Azman-Saini, W., Law, S. H., and Ahmad, A. H. (2010b) 'FDI and Economic Growth: New Evidence on the Role of Financial Markets'. Economics Letters, 107(2), 211-213. https://doi.org/10.1016/j.econlet.2010.01.027

Balasubramanyam, V. N., Salisu, M., \& Sapsford, D. (1996). Foreign direct investment and growth in EP and IS countries'. Economic Journal, 106(434), 92-105. https://doi.org/10.2307/2234933

Barro, R.J., Xavier, Sal-i-Martin, (1995), Economic Growth, Cambridge, MA: NBER.

Bekaert, G., Harvey, C. R., \& Lundblad, C. (2005). Does Financial Liberalization Spur Growth. Journal of Financial Economics, 77(1), 3-55. https://doi.org/10.1016/j.jfineco. 2004.05.007

Bekaert, G., Harvey, C. R., \& Lundblad, C. (2011). Financial Openness and Productivity'. World Development, 39(1), 1-19. https://doi.org/10.1016/j.worlddev.2010.06.016

Bénassy-Quéré, A., Coupet, M., \& Mayer, T. (2007). Institutional determinants of foreign direct investment. World economy, 30(5), 764-782. https://doi.org/10.1111/j.1467-9701. 2007.01022.x

Bhattacharyya, R. (2012). The Opportunities and Challenges of FDI in Retail in India. IOSR Journal of Humanities and Social Science, 5(5), 99-109. https://doi.org/10.9790/0837 $-05599109$

Borensztein, E., De Gregorio, J., Lee, J. W., (1995), How Does Foreign Direct Investment Affect Economic Growth. National Bureau of Economic Research, Cambridge, MA. NBER Working Paper Series n ${ }^{\circ} 5057$.

Bouchoucha N., S. B. Ammou (2015), Political and Institutional Determinants of Foreign Direct Investment: An application for MENA Region Countries. International Journal of Science and Research, 4(8).

Buckley, P. J., \& Casson, M. (2010). Edith Penrose's theory of the growth of the firm and the strategic management of multinational enterprises. In The Multinational Enterprise Revisited (pp. 277-300). Palgrave Macmillan, London. https://doi.org/10.1057/9780230250468

Busse, M., C. Hafeker (2005), Political Risk, Institutions and Foreign Direct Investment, Hamburgisches Welt Wirtschafts Archiv (HWWA), Discussion Paper 315. https://doi.org/10.2139/ssrn.704283

Carkovic, M., \& Levine, R. (2005). Does foreign direct investment accelerate economic growth?. Does foreign direct investment promote development, 195.

Caves, R. E. (1971). International corporations: The industrial economics of foreign investment. Economica, 38(149), 1-27. https://doi.org/10.2307/2551748

Chakraborty, C, . \& Peter, N. (2007). Economic Reforms, FDI, and Economic Growth in India: A Sector Level Analysis. World Development, 36(7), 1192-1212. https://doi.org/10.1016/j. worlddev.2007.06.014 


\section{Macrothink}

Issues in Economics and Business

ISSN 2377-2301

2020, Vol. 6, No. 2

Choong, C. K., Yusop, Z., \& Soo, S-C. (2004). Foreign Direct Investment, Economic Growth, and Financial Sector Development: A Comparative Analysis. ASEAN Economic Bulletin, 21(3), 278-289.

Cleeve, E. (2008). How Effective Are Fiscal Incentives to Attract FDI to Sub-Saharan Africa? The Journal of Developing Areas, 42(1), 135- 153.

Cooray, A., Mallick, S., \& Dutta, N. (2014), 'Gender-specific Human Capital, Openness and Growth: Exploring the Linkages for South Asia'. Review of Development Economics, 18, 107-122.

Daude, C., \& Stein, E. (2004). The Quality of Institutions and Foreign Direct Investment.

De Mello, L.R. (1999), Foreign Direct Investment-led Growth: Evidence from Time Series and Panel Data. Oxford Economic Paper, 51, 133-151. https://doi.org/10.1093/oep/51.1.133

Demena, B. A. (n.d.). FDI and productivity gains in developing countries: How to make sense of an inconclusive debate? 3.

Demir, F., \& Duan, Y. (2018). Bilateral FDI Flows, Productivity Growth, and Convergence: The North vs. The South. World Development, 101, 235-249. https://doi.org/10.1016/j. worlddev.2017.08.006

Dixit, A. K., Dixit, R. K., \& Pindyck, R. S. (1994). Investment under uncertainty. Princeton university press. https://doi.org/10.1515/9781400830176

Djankov, S., \& Hoekman, B. (2000). Foreign investment and productivity growth in Czech enterprises. The World Bank Economic Review, 14(1), 49-64. https://doi.org/10.1093/ wber/14.1.49

Dunning, J. H. (2002). The selected essays of John H. Dunning (Vol. 1). Edward Elgar Publishing.

Dunning, J. H., \& Lundan, S. M. (2008). Multinational enterprises and the global economy. Edward Elgar Publishing.

Dunning, J. H., \& Lundan, S. M. (2008). Theories of foreign direct investment. John H. Dunning e Sarianna M. Lundan (org.), Multinational Enterprises and the Global Economy, Cheltenham: Edward Elgar Publishing Limited, 79-115.

Dupasquier, C., \& Osakwe, P. N. (2006). Foreign direct investment in Africa: Performance, challenges, and responsibilities. Journal of Asian Economics, 17(2), 241-260. https://doi.org/10.1016/j.asieco.2005.07.002

Eddine, A. S. (n.d.). Financial liber alization, For eign Dir ect investment ( FDI ) and Economic Gr owth: A Panel Dynamic Data Validation. 17.

Elkhuizen, L., Hermes, N., Jacobs, J., \& Meesters, A. (2018). Financial development, financial liberalization and social capital. Applied Economics, 50(11), 1268-1288. https://doi.org/10.1080/00036846.2017.1358446

Ertur, C., Koch, W., 2007. Growth, technological interdependence and spatial externalities: theory and evidence. J. Appl. Econ. 22, 1033-1062. https://doi.org/10.1002/jae.963

Fernandes, A., \& Paunov, C. (2012). Foreign direct investment in services and manufacturing productivity: Evidence for Chile. Journal of Development Economics, 97(2), 305-321. https://doi.org/10.1016/j.jdeveco.2011.02.004 
Fons-Rosen, C., Kalemli-Ozcan, S., Sorensen, B. E., Villegas-Sanchez, C., \& Volosovych, V. (2014). Foreign ownership, selection, and productivity. CompNet, Working Paper, March.

Francis, J., Zheng, C., \& Mukherji, A. (2009). An Institutional Perspective on Foreign Direct Investment: A Multi-level Framework. Management International Review, 49(5), 565-583. https://doi.org/10.1007/s11575-009-0011-x

$\mathrm{Fu}, \mathrm{X}$. (2008). Foreign direct investment, absorptive capacity and regional innovation capabilities: Evidence from China. Oxford Development Studies, 36(1), 89-110. https://doi.org/10.1080/13600810701848193

$\mathrm{Fu}, \mathrm{X}$., \& Gong, Y. (2011). Indigenous and foreign innovation efforts and drivers of technological upgrading: Evidence from China. World Development, 39(7), 1213-1225. https://doi.org/10.1016/j.worlddev.2010.05.010

Fujimori, A., \& Sato, T. (2015). Productivity and technology diffusion in India: The spillover effects from foreign direct investment. Journal of Policy Modeling, 37(4), 630-651. https://doi.org/10.1016/j.jpolmod.2015.04.002

Gao, T. (2005). Foreign Direct Investment and Growth Under Economic Integration. Journal of International Economics, 67, 157-174. https://doi.org/10.1016/j.jinteco.2004.11.003

Girma, S., Gong, Y., Görg, H., \& Lancheros, S. (2015). Estimating direct and indirect effects of foreign direct investment on firm productivity in the presence of interactions between firms. Journal of International Economics, 95(1), 157-169. https://doi.org/10.1016/ j.jinteco.2014.11.007

Görg, H., \& Greenaway, D. (2004). Much ado about nothing? Do domestic firms really benefit from foreign direct investment?. The World Bank Research Observer, 19(2), 171-197. https://doi.org/10.1093/wbro/lkh019

Grossman, G. M., Helpman, E. (1991). Innovation and Growth in the Global Economy. (Cambridge MA, MIT Press).

Haddad, M., \& Harrison, A. (1993). Are there positive spillovers from direct foreign investment? : Evidence from panel data for Morocco. Journal of development economics, 42(1), 51-74. https://doi.org/10.1016/0304-3878(93)90072-U

Hallam, D. (2011). International investment in developing country agriculture-Issues and challenges. Food Security, 3(S1), 91-98. https://doi.org/10.1007/s12571-010-0104-1

Hansen, H., \& Rand, J. (2006) 'On the Causal Links between FDI and Growth in Developing Countries'. The World Economy, 29(1), 21-41. https://doi.org/10.1111/j.1467-9701.2006. 00756.x

Harris, R., \& Moffat, J. (2013). The direct contribution of FDI to productivity growth in Britain, 1997-2008. The World Economy, 36(6), 713-736. https://doi.org/10.1111/twec.12059

Harris, R., \& Robinson, C. (2002). The effect of foreign acquisitions on total factor productivity: plant-level evidence from UK manufacturing, 1987-1992. Review of Economics and Statistics, 84(3), 562-568. https://doi.org/10.1162/003465302320259556

Haskel, J. E., Pereira, S. C., \& Slaughter, M. J. (2007). Does inward foreign direct investment boost the productivity of domestic firms?. The review of economics and statistics, 89(3), 482-496. https://doi.org/10.1162/rest.89.3.482 
Hausmann, R., \& Fernández-Arias, E. (n.d.). Foreign Direct Investment: Good Cholesterol? 46.

Hermes, N., Lensink, R. (2003), Foreign Direct Investment, Financial Development and Economic Growth. The Journal of Development Studies, 40(1), 42-161. https://doi.org/10.1080/00220380412331293707

Herzer, D., Klasen, S., \& Nowak-Lehmann D., F. (2008). In search of FDI-led growth in developing countries: The way forward. Economic Modelling, 25(5), 793-810. https://doi.org/10.1016/j.econmod.2007.11.005

Hill, C. (2008). International business: Competing in the global market place. Strategic Direction. https://doi.org/10.1108/sd.2008.05624iae.001

Hsiao, F. S. and Hsiao, M. W. (2006) 'FDI, Exports, and GDP in East and Southeast Asia Panel Data Versus Time-Series Causality Analyses'. Journal of Asian Economics, 17(6), 1082-1106. https://doi.org/10.1016/j.asieco.2006.09.011

Hymer, S. H. (1976). The international operations of national firms: A study of foreign direct investment.

Jaiblai, P., \& Shenai, V. (2019). The Determinants of FDI in Sub-Saharan Economies: A Study of Data from 1990-2017. International Journal of Financial Studies, 7(3), 43. https://doi.org/10.3390/ijfs 7030043

Jasay, A. E. D. (1960). The social choice between home and overseas investment. The Economic Journal, 70(277), 105-113. https://doi.org/10.2307/2227485

Kaufmann, D. (2003). Rethinking governance: empirical lessons challenge orthodoxy. Available at SSRN 386904. https://doi.org/10.2139/ssrn.386904

Keller, W., \& Yeaple, S. (2003). Multinational Enterprises, International Trade, and Productivity Growth: Firm Level Evidence from the United States, NBER Working Paper 9504.

Kemp, M. C. (1964). The Pure Theory of International Trade Englewood Cliffs.

Kindleberger, C. P. (1969). American business abroad. The International Executive, 11(2), 11-12. https://doi.org/10.1002/tie.5060110207

Knickerbocker, F. T. (1973). Oligopolistic reaction and multinational enterprise. The International Executive, 15(2), 7-9. https://doi.org/10.1002/tie.5060150205

Kose, M. A., Prasad, E. S., \& Terrones, M. E. (2009). Does openness to international financial flows raise productivity growth? Journal of International Money and Finance, 27. https://doi.org/10.2139/ssrn.1331615

Liu, W. S., Agbola, F. W., \& Dzator, J. A. (2016). The Impact of FDI Spillover Effects on Total Factor Productivity in the Chinese Electronic Industry: A Panel Data Analysis'. Journal of the Asia Pacific Economy, 21(2), 217-234. https://doi.org/10.1080/13547860.20_15.113 7473

Liu, Z. (2008) 'Foreign Direct Investment and Technology Spillovers: Theory and Evidence'. Journal of Development Economics, 85(1), 176-193.

MacDougall, G. D. A. (1960). The benefits and costs of private investment from abroad: A theoretical approach 1. Bulletin of the Oxford University Institute of Economics \& Statistics, 
22(3), 189-211. https://doi.org/10.1111/j.1468-0084.1960.mp22003002.x

Mallick, S., \& Moore, T. (2008). Foreign Capital in a Growth Model'. Review of Development Economics, 12(1), 143-159. https://doi.org/10.1111/j.1467-9361.2008.00437.x

Mastromarco, C., Serlenga, L., \& Shin, Y. (2013). Globalisation and technological convergence in the EU. J. Product. Anal. 40, 15-29. https://doi.org/10.1007/s11123012-0308-9

Mauro, P. (1995). Corruption and growth. The quarterly journal of economics, 110(3), 681-712.

Newman, C., Rand, J., Talbot, T., \& Tarp, F. (2015). Technology transfers, foreign investment and productivity spillovers. European Economic Review, 168-187.

Nunnenkamp, P. (2001). Foreign direct investment in developing countries: What policymakers should not do and what economists don't know. Inst. für Weltwirtschaft.

Okada, K., \& Samreth, S. (2014). How does Corruption Influence the Effect of Foreign Direct Investment on Economic Growth?'. Global Economic Review, 43(3), 207-220. https://doi.org/10.1080/1226508X.2014.930671

Omran, M., \& Bolbol, A. (2003). Foreign Direct Investment, Financial Development, and Economic Growth: Evidence from the Arab Countries. Review of Middle East Economics and Finance, 1, 231-249.

Paul, C. J. M., \& Yasar, M. (2009). Outsourcing, productivity, and input composition at the plant level. Canadian Journal of Economics/Revue canadienne d'économique, 42(2), 422-439. https://doi.org/10.1111/j.1540-5982.2009.01514.x

Peng, M. (2009). Institutions, cultures and ethics. Global Strategic Management, Cincinnati: South-Western Cengage Learning, 90-122.

Saidi, Y. A. Ochi and H. Ghadri, 2013, Governance and FDI Attractiveness : Some Evidence from Developing and Developed Countries. Global Journal of Management and Business Research Finance, 13(6).

Shleifer, A., \& Vishny, R. W. (1993). Corruption. The quarterly journal of economics, 108(3), 599-617. https://doi.org/10.2307/2118402

Siddiqui, D. A., \& Ahmed, Q. M. (2013). The effect of institutions on economic growth: A global analysis based on GMM dynamic panel estimation. Structural Change and Economic Dynamics, 24, 18-33. https://doi.org/10.1016/j.strueco.2012.12.001

Silajdzic, S., \& Mehic, E. (2015). Knowledge spillovers, absorptive capacities and the impact of FDI on economic growth: Empirical evidence from transition economies. Procedia-Social and Behavioral Sciences, 195(33), 614-623. https://doi.org/10.1016/j.sbspro.2015.06.142

Singh, A. (2003). Capital Account Liberalization, Free Long-Term Capital Flows, Financial Crises and Economic Development. Eastern Economic Journal, 29(2), 191-216.

Slesman, L., Baharumshah, A. Z., \& Wohar, M. E. (2015). Capital Inflows and Economic Growth: Does the Role of Institutions Matter?'. International Journal of Finance \& Economics, 20(3), 253-275. https://doi.org/10.1002/ijfe.1514

Tanna, S., Li, C., and De Vita, G. (2018) 'The Role of External Debt in the Foreign Direct Investment - Growth Relationship'. International Journal of Finance \& Economics, 23(4), 
393-412. https://doi.org/10.1002/ijfe.1628

Vernon, R. (2015). International investment and international trade in the product cycle. In International Business Strategy (pp. 35-46). Routledge.

Wei, S. J. (1997). Why is corruption so much more taxing than tax? Arbitrariness kills (No. w6255). National bureau of economic research. https://doi.org/10.3386/w6255

Wei, S. J. (2000). How taxing is corruption on international investors? Review of economics and statistics, 82(1), 1-11. https://doi.org/10.1162/003465300558533

Wernick, D., A., J. Haar, Sharma, L. (2014). The Impact of governing Instituions on Foreign Direct Investment Flows: Evidence from Asian Nations. International Journal of Business administration, 5(2), 1-12. https://doi.org/10.5430/ijba.v5n2p1

Wheeler, D., \& Mody, A. (1992). International investment location decisions: The case of US firms. Journal of international economics, 33(1-2), 57-76. https://doi.org/10.1016/0022-1996 (92)90050-T

Xiaoying Li (University of Nottingham, UK) XiamingLui (University of survey, UK), (2004), Foreign Direct Investment and Economic Growth: An Increasingly Endogenous Relationship. World Development, 33(3), 393-407. https://doi.org/10.1016/j.worlddev.2004.11.001

Xu, H., Wan, D., \& Sun, Y. (2014). Technology spillovers of foreign direct investment in coastal regions of east China: A perspective on technology absorptive capacity. Emerging Markets Finance and Trade, 50(1S), 96-106. https://doi.org/10.2753/REE1540-49 6X5001S106

\section{Copyright Disclaimer}

Copyright for this article is retained by the author(s), with first publication rights granted to the journal. This is an open-access article distributed under the terms and conditions of the Creative Commons Attribution license (http://creativecommons.org/licenses/by/4.0/). 